\title{
Systematic investigation of stresses in concentrically clamped bolted joints using the finite element method
}

\author{
Bozca M. \\ Yildiz Technical University, Mechanical Engineering Faculty, \\ 34349 Yildiz, Istanbul, Turkey
}

(Received 7 May 2020; Revised 4 August 2020; Accepted 11 August 2020)

\begin{abstract}
In this paper, the systematic investigation of the stresses occurring in a rod bearing cap bolted joint is carried out by considering a concentrically clamped rod bearing cap bolted joint. The aim of this study is to develop a $2 \mathrm{D}$ finite element model to determine occurring stress in bolted joints during all cases of bolted joint and to compare VDI-Directives. For this aim, the bolt load and part load are analytically calculated based on the axial load. The assembly stress, working stress, and alternating stress are calculated and simulated based on the introduction of a load factor $n$. A 2D finite element model is developed. For this aim, the global stiffness matrix $[K]$ is obtained and the boundary conditions and load (such as force $[F]$ and moment $[M]$ ) are applied. By solving algebraic equations of the system in terms of nodal displacement $\{u\}$ and $\{\theta\}$, we obtain assembly stresses $\sigma_{v}$, working stress $\sigma_{B}$ and alternating stress $\sigma_{a}$ in each element of the structure. The finite element equations for the bolt are established. The assembly stress, working stress, and alternating stress are calculated using the developed finite element model. The analytical calculation results and finite element calculation results are compared and are found to be highly similar in terms of the assembly stress, working stress, and alternating stress. Increasing the stiffness rate of the bolt causes the increase of the bolt load and alternating stresses; in contrast, increasing the stiffness rate of the clamp causes the decrease of the bolt load and alternating stresses. The stiffness of the bolt should be as low as possible to reduce the maximum bolt load and stress of the bolt cross-sections. However, the stiffness of the clamped part should be as high as possible. Additionally, increasing the load introduction factor causes the increase of the bolt load. Thus, for concentrically bolted joints, increasing the load introduction factor causes the increase of the assembly stress and alternating stress.
\end{abstract}

Keywords: bolted joints, assembly stress, working stress, alternating stress, finite element.

2010 MSC: $74 \mathrm{~S} 05$

DOI: $10.23939 / \mathrm{mmc} 2020.02 .345$

\section{Introduction}

Bolted joints are commonly used in machine and steel construction. Ideally, bolted joints should safely withstand all working and load conditions. Thus, the design of bolted joints must satisfy the selection of the bolted joint parameters, such as the preload, tightening factor, and bolt material.

This study aimed to develop a finite element model for concentrically clamped rod bearing cap bolted joints. For this purpose, a rod bearing cap bolted joint was considered. The assembly stress, working stress, and alternating stress are calculated and simulated based on the load introduction factor $n$.

This study systematically investigated the stresses on a concentrically clamped bolted joint by considering a rod bearing cap bolted joint. The bolt is of the M12 type and is composed of 12.9 steel materials. The bolt load and part load are analytically calculated depending on the axial load according to the VDI 2230 directive. In this study, both analytical and finite element calculations were based on the VDI 2230 directive. 
All obtained equations used in the finite element calculation were written in matrix form and the results were obtained by matrix operations.

According to the literature review, studies on bolted joints can be classified into finite elements modelling, fatigue life testing, and geometrical parameter analysis.

According to the literature review, studies on bolted joints can be classified into those considering finite elements modelling and fatigue life testing. These types of studies are explained in more detail in this section. The results presented in previous studies are described below.

Many studies have been conducted in the literature based on the finite element method of bolted connections.

The bolt-plate assembly was modelled using the finite element technique, including super elements to solve the contact problem of the integrated preload and external load. The external load distribution on the bolt-plate assembly was analysed by focusing on the part of the external loads that affected the bolt [1].

A new 3D parametric finite element model for designing two-bolted joints was developed. This model considered an eccentric compression load. A numerical model for designing two threaded fastener connections and calculating the displacements and loads at each node of the bolted joint was presented. Bolts were subjected to normal and tangential stresses under the tensile loading condition. Von Misses criteria were applied for statically calculating the bolt dimensions under tensile loading [2].

The aim of the developed finite elements model was to determine the local stress at the first thread root to observe fatigue damage initiation. By using a local approach, the fatigue behaviour of bolts under axial loads was considered based on material behaviours. The local stress at the first thread root was determined by using the finite element model of the bolt. The bolt behaviour was characterised with the obtained numerical results by using the Dang Van multi-axial fatigue criterion. These results were experimentally correlated with the number of cycles to failure. The lifetime in terms of the failure probability was predicted by using the statistical Gauss method [3].

The stress concentration distribution in the bolted joints was studied using an asymmetric finite element model. The different geometric designs presented in the literature were compared to achieve the best design to reduce stress concentrations. The design modifications include grooves and steps on the bolts and nuts. Additionally, the bolt shank diameter was reduced [4].

A finite element modeling method was presented for a bolt-nut assembly. The first step is a linear calculation of 2D plates and bar elements. The second step is a non-linear calculation of 3D solids. In the non-linear calculation method, the nut and bolt surfaces and bearing stresses were considered in the joint modelling. Analytical calculations were included in the static tests and compared with the finite element calculation results. Furthermore, the effects of element meshing on the nut and bolt-nut assembly contact surfaces as well as the contact types were analysed for the 3D models [5].

Four types of finite element models were considered: a solid bolt model, a coupled bolt model, a spider bolt model, and a boltless model. All of the developed models included the preloaded effect and contact behaviour. The solid bolt model provided the most reliable responses that were also close to the experimental results. The coupled bolt model was the most effective in terms of CPU time [6].

Many studies have been conducted in the literature on fatigue life tests of bolted connections.

The fatigue strength of the bolts loaded in axial tension was investigated experimentally. Tests were conducted under the static loading condition to determine the tightened bolt behaviour in the applied conditions. The external load was increased gradually, and the elongation of the bolt was measured. The increase in the bolt force and a decrease in the clamping force in the bolted assembly could be determined according to these measurements [7].

The effects of embedding and self-loosening of the bolted connection have also been analysed via tests on single bolted lap joints. The amount of static embedding primarily depended on the coating system. If there was a cyclic displacement in the joint, even uncoated connections lost up to $40 \%$ of the preload. Self-loosening tests demonstrated the importance of several parameters, including the clamping length and amount of displacement [8]. 
Relaxation of contact pressure and self-loosening in dynamic bolted joints were investigated. It was concluded that bolted joints are widely loaded by the dynamic load with various vibration frequencies. Therefore, these vibrations can cause a loss in clamping pressure. Furthermore, this vibrational loosening can cause serious failures [9].

Some factors affecting the loosening failure of bolted joints under vibration using finite element analysis were presented. A 3D finite element model of bolted joints was developed. The effects of several factors on loosening under transverse vibration loading were investigated [10].

For reliability testing, dynamically loaded bolted joints were developed for the vibration test according to DIN 65151. This testing was performed to determine the possible relation between the residual preload in the bolted connections and external forces as a function of time. For each test, different speeds were used for bolted joint assembly, and the screw preloading decreased with increases in the time duration of the test. Residual stresses in bolted connections in which the test falls below $\% 5 R_{P 0,2}$ can be regarded as insufficient, indicating a total breakdown of the screw connection. Experiments have shown that a high-speed tightening of the locking nut DIN 985 has an effect on the behaviour of the following secured bolted joint [11].

In the literature, finite element solutions are generally made on solid models. When two-dimensional finite element solutions are made, they are not compared with analytical solutions. Furthermore, the elasticity of the elastic bolts has not been studied as in these studies.

In this study, the elasticity of the elastic bolt has been analyzed both analytically and by a finiteelement method in detail.

Also in the literature, there are many studies on the fatigue behavior of bolts; there are a lot of studies on the material and loading types of bolts and vibration.

In this study, the variable stress under the dynamic load conditions of the bolt is presented by associating it with the elasticity of the bolt.

This study can be summarized due to the finite element method used in engineering applications.

Also, the finite element method is taught in engineering education. It is aimed to show that conventional bolt calculations can also be solved with the finite element method. In addition, it is aimed to show the basics of mathematical problems solved through solid models.

In addition, it is aimed to demonstrate the utility of elasticity of elastic bolts under dynamic loading conditions by the numerical application.

In this study, stresses on elastic bolts are focused. The subject of this study is only to examine the parameters that are effective in calculating elastic bolts. The problem of contact of the connected parts is the subject of another study, as a result of both the pre-tensile force and the operating force applied to the bolts. Furthermore, the study of eccentrically mounted bolts is another research subject.

\section{Methods and materials}

A finite element model was developed for a concentrically clamped rod bearing cap bolted joint. Both the bolt and part were modelled by the finite element method. To obtain a finite element model of the rod bearing cap bolted joint, the stiffnesses of the bolt and part were modelled according to the finite element method.

The bolt was discretised into 14 finite elements and was considered a bar with a variable cross section supporting a preload and axial load. The clamped part was discretised into 12 finite elements. The clamped part was considered as a cylindrical element with a hole supporting a preload and axial load. First, the equivalent stiffness for each element of the bolt in terms of tensile stress and torsional stress was calculated during the finite element modelling. After determining the deformation values of each section, the local stresses were calculated according to Hooke's Law. The obtained nominal stresses and torsional stresses were used in the equivalent stress equations, and the preload stress and assembly stresses were calculated. Then, a stiffness matrix of the clamped parts was obtained. Thus, the alternating stress depending on the stiffnesses of the bolt and clamped parts were calculated.

Mathematical Modeling and Computing, Vol. 7, No. 2, pp. 345-365 (2020) 
The obtained finite element calculation results and analytical calculation results were compared. The finite element calculation results were highly similar to the analytical calculation results for the assembly stress, working stress and alternating stress. The obtained finite element model was valid for calculating all of the stresses on concentrically clamped bolted joints, including the assembly stress, working stress and alternating stress. Increasing the load introduction factor causes the bolt load to increase. Thus, increasing the load introduction factors results causes the assembly stress and alternating stress to increase for concentrically bolted joints.

Load and deformation condition. During the assembly of the joint, a preload $F_{V}$ is applied, which produces a clamp load $F_{K}$ at the interface. The preload and deformation conditions are shown in Fig. 1, and the joint diagram of the preload condition is shown in Fig. 2. The stiffness rate of the bolt $R_{S}$ during the assembly of the joint under a preload is written as follows [12-15].

$$
R_{S}=\frac{F_{V}}{f_{S}}
$$

where $f_{S}$ is the deformation of the bolt under a preload.

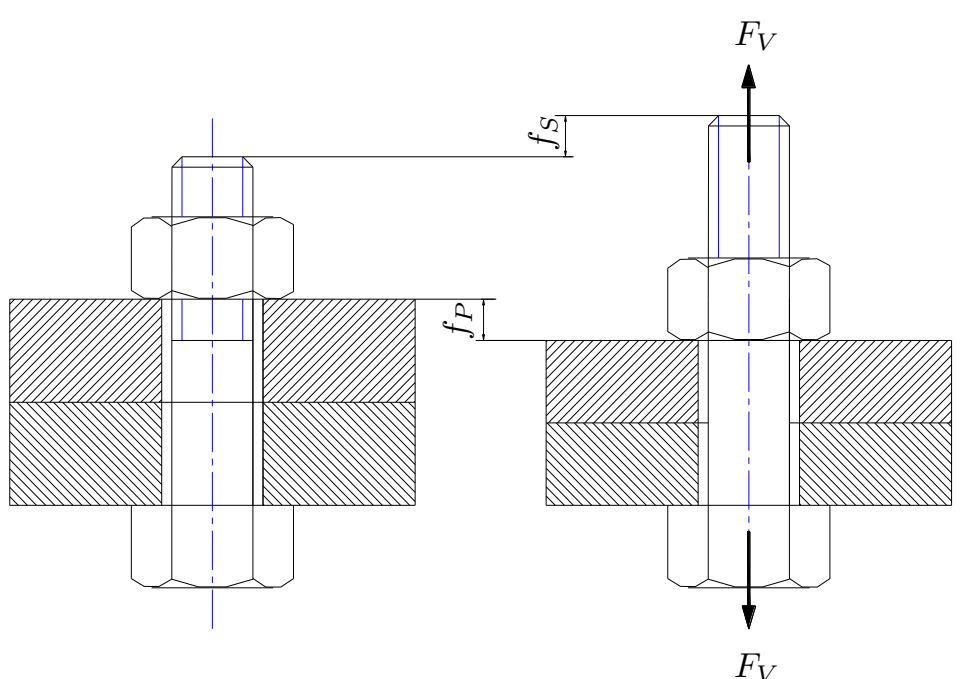

Fig. 1. Preload and deformation conditions.

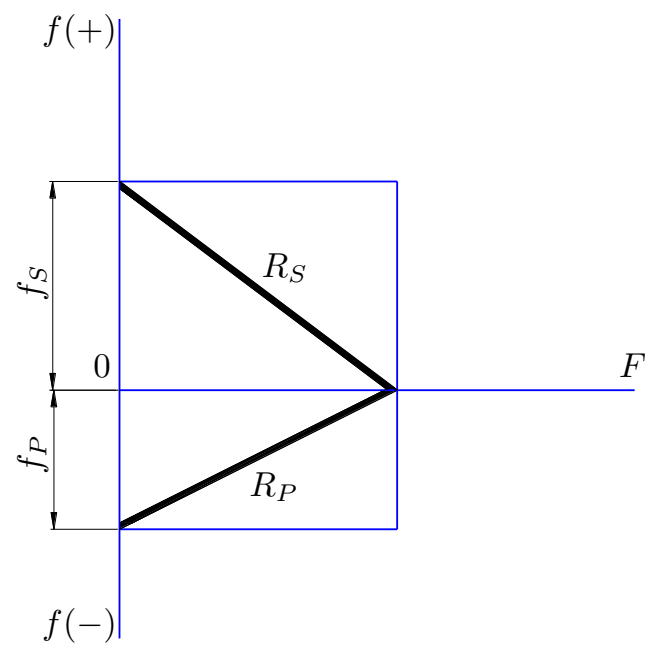

Fig. 2. Joint diagram of the preload condition.

In the joint diagram of the preload condition, the preload is plotted on the horizontal axis and the deformation is plotted on the vertical axis. The characteristic line for the stiffness rate of the bolt is obtained by drawing a line between the preload point and bolt deformation point. Similarly, the characteristic line for the stiffness rate of the part is obtained by drawing a line between the preload point and part deformation point.

The stiffness rate of the plate, $R_{P}$, during the assembly of the joint under a preload is written as follows:

$$
R_{P}=\frac{F_{V}}{f_{P}}
$$

where $f_{P}$ is the deformation of the plate under a preload.

An axial working load $F_{A}$, introduced via the clamped parts and acting on the bolt, is proportionally transmitted via the clamped region of the interface as well as via the bolt. The proportion of the working load loading the bolt in addition to the preload is designed as an additional bolt $F_{S A}$, whereas the remaining proportion $F_{P A}$ relieves the clamped parts. The axial load-deformation condition is shown in Fig. 3, and the joint diagram of the axial load condition is shown in Fig. 4. The axial load $F_{A}$ is written as follows [12-15].

$$
F_{A}=F_{S A}+F_{P A} .
$$


The stiffness rate of the bolt $R_{S}$ under the axial working load is

$$
R_{S}=\frac{F_{S A}}{f_{A}}
$$

where $f_{A}$ is the deformation of the bolt under an axial load.

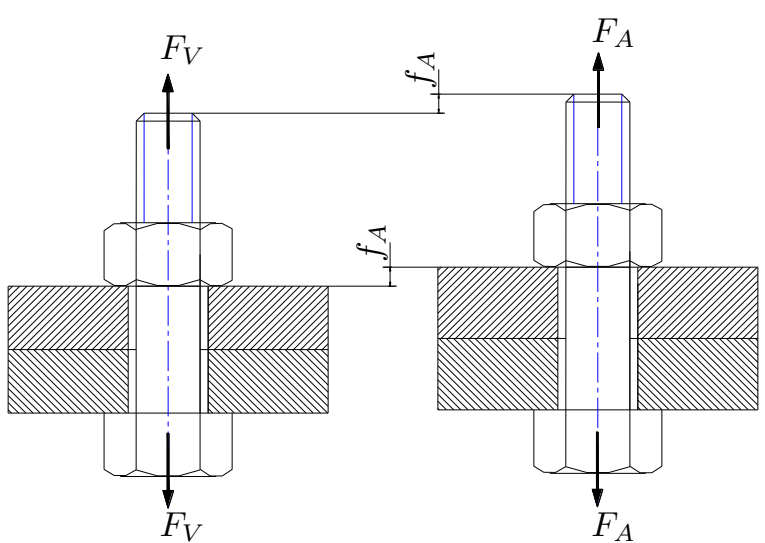

Fig. 3. Axial load and deformation conditions.

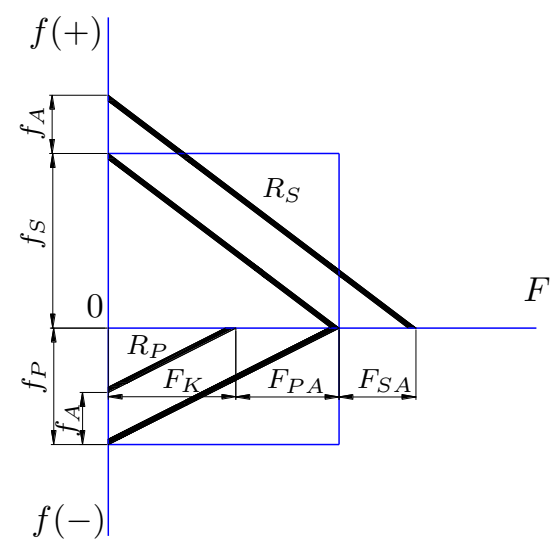

Fig. 4. Joint diagram of the axial load condition.

The stiffness rate of the plate $R_{P}$ under the axial working load is

$$
R_{P}=\frac{F_{P A}}{f_{A}}
$$

where $f_{A}$ is the deformation of the plate under the axial load.

In the joint diagram of the axial load condition, the axial load is plotted on the horizontal axis, and the deformation is plotted on the vertical axis. The characteristic line for the stiffness rate of the bolt is obtained by drawing a line between the axial load point and bolt deformation point. Similarly, the characteristic line for the stiffness rate of the part is obtained by drawing a line between the axial load point and part deformation point.

The characteristic lines for the stiffness rate of the bolt and the stiffness rate of the part are parallel for both the preload condition and axial load condition.

Analysis of the forces and deformation of the bolted joints. The calculation for single-bolted joints is based on the elastic behaviour of the joint in the immediate surroundings of the bolt axis. During the assembly and ser-

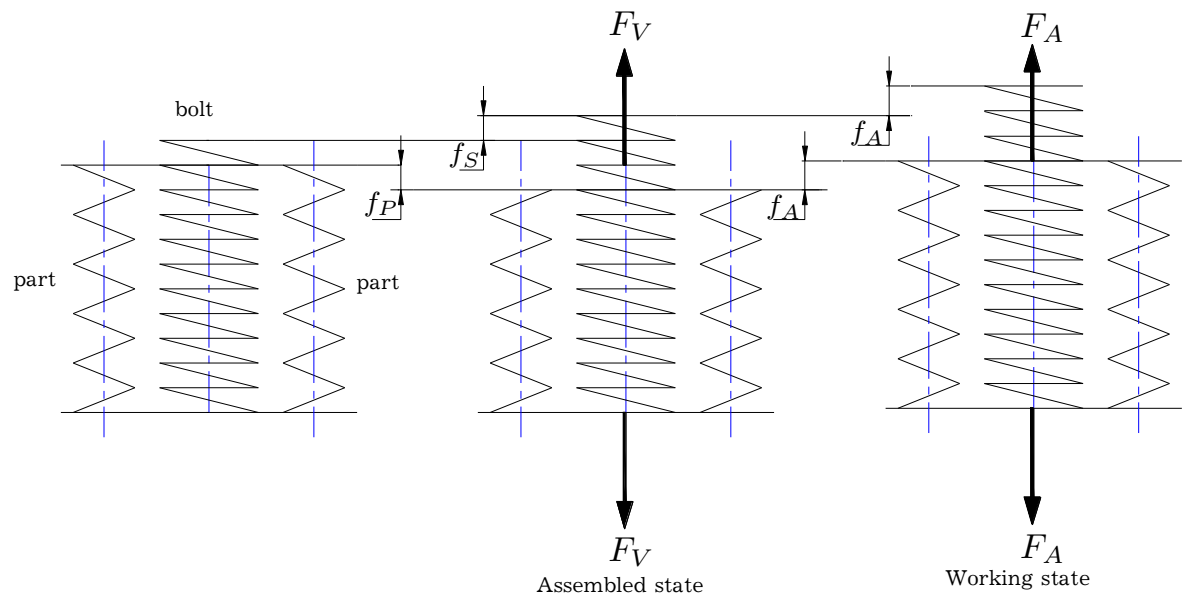

Fig. 5. Axial load and deformation conditions. vice, this region has a considerable effect on the deformation and thus the loading of the bolt [12].

The forces and axial deformation in the single-bolted joint can be described via a simple mechanical spring model. In this model, the bolt and clamped parts are considered as tension and compressing springs with elastic resiliences $\delta_{S}$ and $\delta_{P}$, respectively [12]. The spring model of a bolted joint is shown in Fig. 5. 


\section{Analytical calculation steps}

The calculation steps for the bolted joints primarily involve the determination of the assembly stress $\sigma_{V}$, working stress $\sigma_{B}$, and alternating stress $\sigma_{a}$. A flowchart of the systematic bolted joint design is shown in Fig. 6.

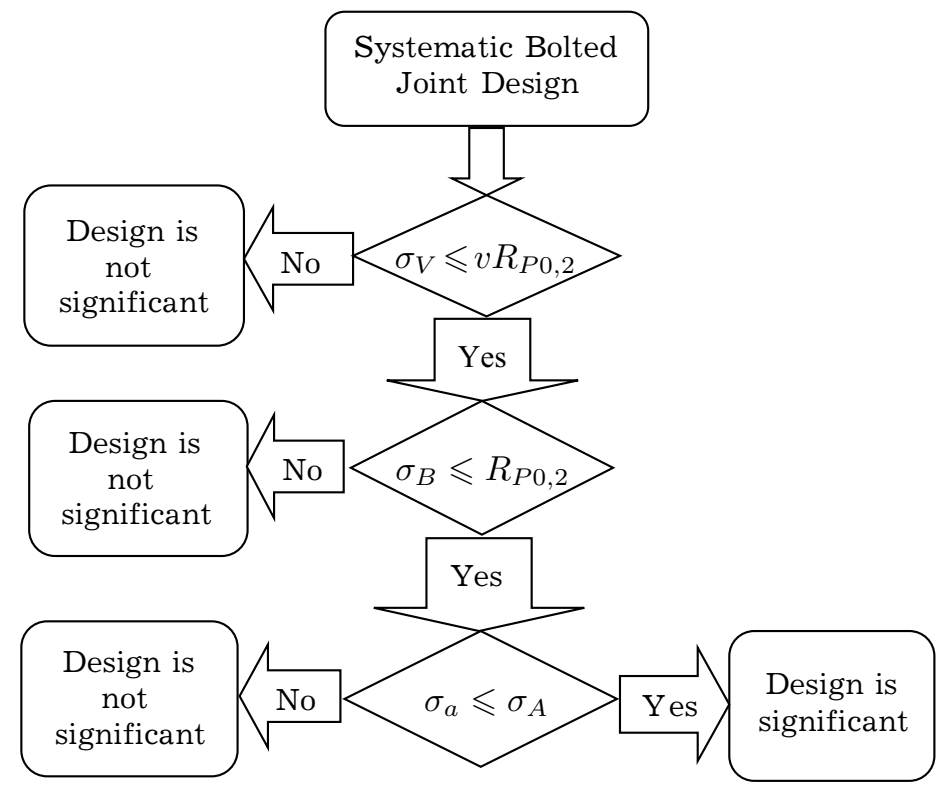

Fig. 6. Flowchart of the systematic bolted joint design.
Determining the tightening factor $\alpha_{A}$. The tightening factor $\alpha_{A}$ considers the scatter of the achievable assembly preload between $F_{V \text { min }}$ and $F_{V \text { max }}$. This factor is determined while considering the tightening and adjusting techniques and, if necessary, the coefficient of friction classes. The tightening factor $\alpha_{A}$ is determined as follows [12-15]:

$$
\alpha_{A}=\frac{F_{V \max }}{F_{V \min }} .
$$

Dividing the working load into $F_{S A}$ and $F_{P A}$. The load factor $\phi$ is the quotient of the additional bolt load $F_{S A}$ and the axial load $F_{A}[12-15]$ :

$$
\phi=\frac{F_{S A}}{F_{A}} \text {. }
$$

The axial additional bolt load $F_{S A}$ is

$$
F_{S A}=\frac{1}{1+R_{P} / R_{S}} F_{A}=\phi F_{A} .
$$

The additional plate load $F_{P A}$ is

$$
F_{P A}=\frac{1}{R_{S} / R_{P}+1} F_{A}=(1-\phi) F_{A} .
$$

By considering the load introduction factor $n$, the additional bolt load $F_{S A}$ is obtained as

$$
F_{S A}=n \phi F_{A},
$$

where the value of the load introduction factor $n$ is between 0 and $1(0<n<1)$. The load introduction factor is shown in Fig. 7.
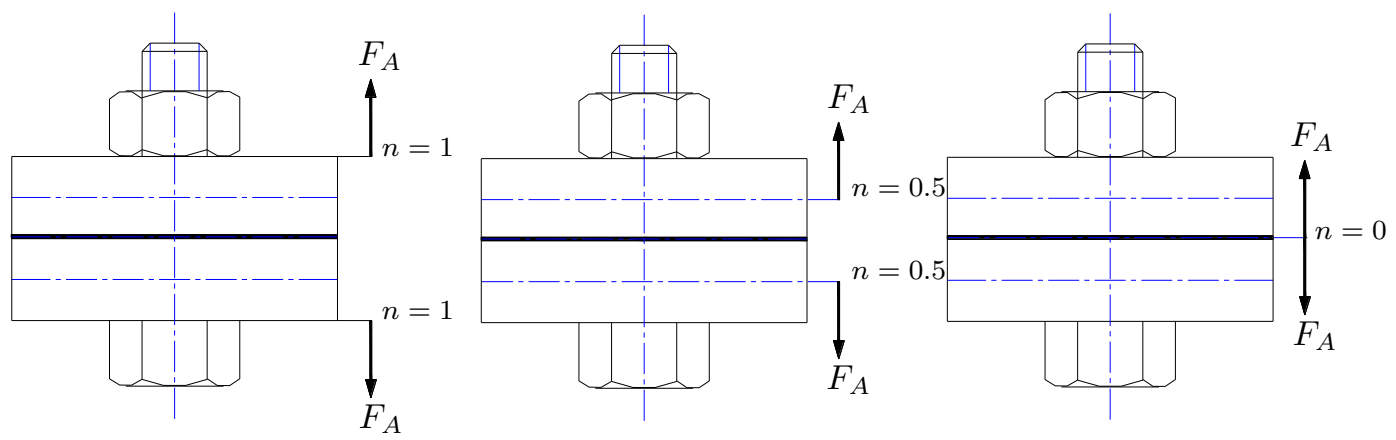

Fig. 7. Load introduction factor $n$. 
Determining the minimum assembly preload $F_{V \text { min }}$. The minimum assembly preload $F_{V \text { min }}$ is equal to the preload $F_{V}$ for the assembly state. The minimum assembly preload $F_{V \text { min }}$ is

$$
F_{V \min }=F_{V} \text {. }
$$

Determining the maximum assembly preload $F_{V \text { max }}$. The maximum assembly preload $F_{V \text { max }}$ is calculated by multiplying the preload $F_{V}$ by the tightening factor $\alpha_{A}$. The maximum assembly preload $F_{V \max }$ is

$$
F_{V \max }=\alpha_{A} F_{V}
$$

Determining the assembly stress $\sigma_{V}$. The assembly preload $F_{V}$ of the bolt serves as a dimension criterion for the nominal diameter of the bolt. For the corresponding strength of the material and with the given friction conditions, the selected bolt must have an associated clamping load $F_{V}$ that is at least as high as the calculated maximum assembly preload $F_{V \max }$ [12]. The assembly stress $\sigma_{V}$ is

$$
\sigma_{V}=\sigma_{r e d, M}=\sqrt{\sigma_{z, M}^{2}+3 \tau_{t}^{2}} \leqslant \nu R_{P 0,2}
$$

where $\sigma_{z, M}$ is the tensile stress in the bolt. The tensile stress $\sigma_{z, M}$ is calculated as

$$
\sigma_{z, M}=\frac{F_{V \max }}{A_{S}}=\frac{\alpha_{A} F_{V}}{A_{S}}
$$

where $A_{S}$ is the stress cross section of the bolt thread according to DIN 13-28. The stress cross section of the bolt $A_{S}$ is calculated as

$$
A_{S}=\frac{\pi}{4} \frac{\left(d_{2}+d_{3}\right)^{2}}{2}
$$

$\tau_{t}$ is the torsional stress in the thread as a result of $M_{G}$. The torsional stress in the thread $\tau_{t}$ is calculated as

$$
\tau_{t}=\frac{M_{G \max }}{W_{t}}
$$

where $M_{G}$ is the proportion of the tightening torque acting on the thread (the thread torque). The thread torque $M_{G}$ is calculated as

$$
M_{G \max }=\alpha_{A} F_{v} \frac{d_{2}}{2} \tan \left(\varphi+\rho^{\prime}\right),
$$

where $\varphi$ is the helix angle of the bolt thread and $\rho^{\prime}$ is the angle of friction. $W_{t}$ is the moment of resistance of the stress cross section of the bolt thread. The moment of resistance of the stress cross section of the bolt thread is calculated as

$$
W_{t}=\frac{\pi}{16} d_{3}^{3}
$$

$\nu$ is the utilisation factor of the yield point stress (the limit of full plasticisation of the cross section at risk) during tightening.

Determining the working stress $\sigma_{B}$. The working stress $\sigma_{r e d, B}$ must not exceed the $R_{P 0,2}$ limit of the bolt material. The working stress $\sigma_{\text {red,B }}$ is

$$
\sigma_{r e d, B}=\sqrt{\sigma_{z}^{2}+3\left(0.5 \tau_{t}\right)^{2}} \leqslant R_{P 0.2}
$$

where $R_{P 0.2}$ is the $0.2 \%$ proof stress of the bolt according to DIN EN ISO 898-1.

Determining the alternating stress $\sigma_{a}$. If the stress in the working case is an alternating stress, the alternating stress $\pm \sigma_{a}$ must not exceed the fatigue limit of the bolt [12]. The alternating stress is

$$
\sigma_{a}=\frac{F_{S A, a}}{A_{S}}=\frac{F_{S A 0}-F_{S A u}}{2 A_{S}}=\frac{F_{S, \max }-F_{S, \min }}{2 A_{S}} \leqslant \sigma_{A}
$$


Calculation quantities. The calculation quantities include the calculation of the elastic resilience of the bolt and the calculation of the elastic resilience of the part.

Elastic resilience of the joint. The resilience of the bolt depends on not only the elastic deformation within the clamp length but also any elastic deformation that occurs outside this region that has an effect on the deformation behaviour of the bolt in the joint [12].

Resilience of the bolt. The bolt consists of a number of individual elements, which can readily be substituted by cylindrical bodies of various lengths $l_{i}$ and cross sections $A_{i}$ [12].

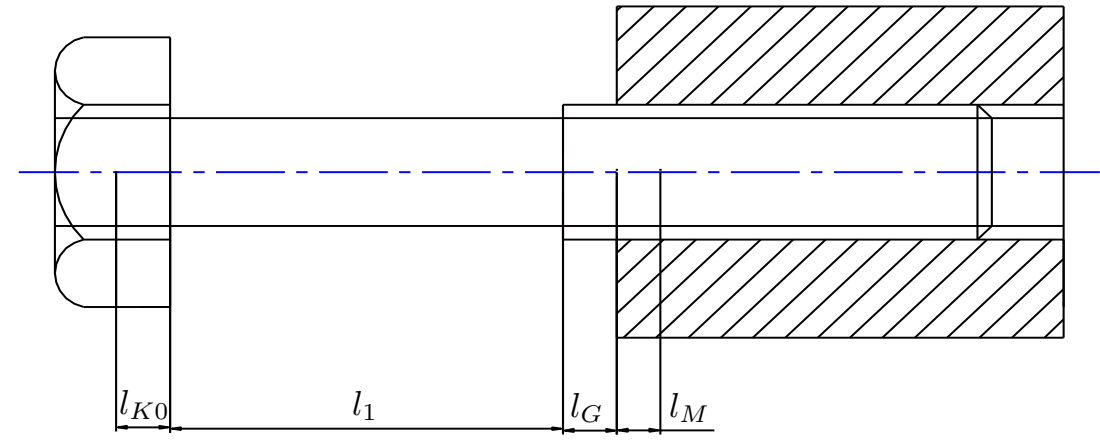

Fig. 8. Deformation region of the bolt.

In the bolt, the cylindrical elements are arranged in a row such that the total elastic resilience $\delta_{S}$ is determined by adding the resilience of the individual cylindrical elements within the clamp length $\delta_{i}$ and the further deformation region [12]. The deformation region of the bolt is shown in Fig. 8.

$$
\delta_{S}=\delta_{S K}+\delta_{1}+\delta_{2}+\ldots+\delta_{G e w}+\delta_{G M}
$$

The resilience of the bolt is calculated as

$$
\delta_{S}=\frac{1}{R_{S}}=\frac{1}{E_{S}}\left(\frac{l_{K 0}}{A_{N}}+\frac{l_{1}}{A_{T}}+\frac{l_{G}}{A_{d 3}}+\frac{l_{M}}{A_{N}}\right),
$$

where $A_{N}$ is the nominal cross section of the bolt, $A_{T}$ is the necked-down cross section or reduced-shank cross-section of the bolt, and $A_{d 3}$ is the cross section of the thread at a minor diameter according to DIN 13-28.

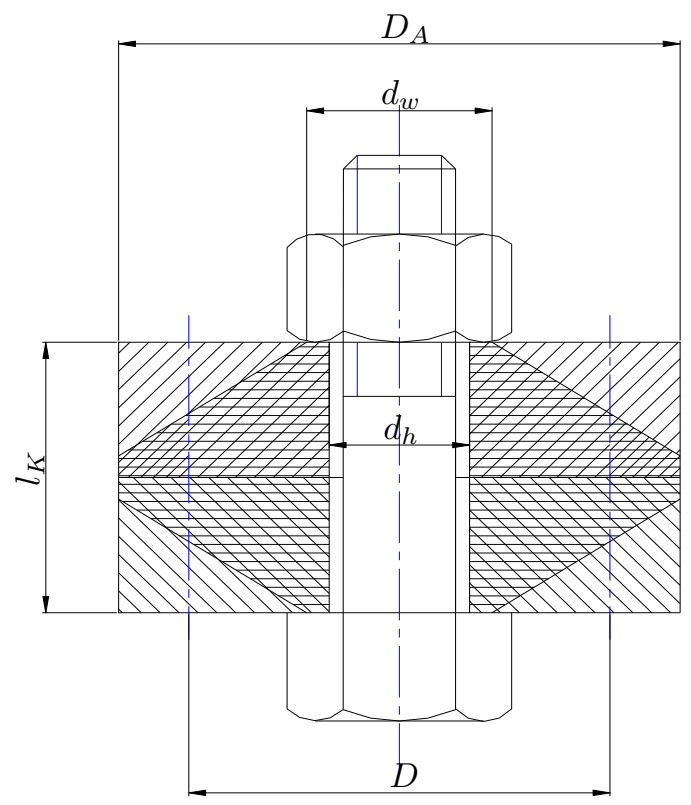

Fig. 9. Deformation region (cone) of the clamped part.

Resilience of the part. The elastic resilience $\delta_{P}$ of the concentrically clamped parts is obtained for this case [12]. The deformation region of the clamped parts is shown in Fig. 9. 


$$
\delta_{P}=\frac{1}{R_{P}}=\frac{\frac{2}{w d_{h} \tan \varphi_{E}} \ln \left[\frac{\left(d_{w}+d_{h}\right)\left(D_{A}-d_{h}\right)}{\left(d_{w}-d_{h}\right)\left(D_{A}+d_{h}\right)}\right]+\frac{4}{D_{A}^{2}-d_{h}^{2}}\left[l_{K}-\frac{D_{A}-d_{w}}{w \tan \varphi_{E}}\right]}{E_{P} \pi},
$$

where $w$ is the joint coefficient for the type of bolted joint, $d_{h}$ is the hole diameter of the clamped parts, $\varphi_{E}$ is the angle of the substitutional deformation cone for the tapped thread joints, and $d_{w}$ is the outer diameter of the plane head bearing surface of the bolt (at the inlet of the transition radius of the head). In general, the bearing surface outer diameter and $D_{A}$ can be substituted for the diameter of the basic solid at the interface; if the interface area differs from the circular form, the average diameter is used [12].

\section{Finite elements method}

The basic steps of the finite element method analysis are the discretisation of the solution domain into a finite number of elements, writing the static equilibrium for each node, obtaining the global stiffness matrix, applying the boundary conditions and load, solving the algebraic equations of the system, and obtaining the stress of each element. The flowchart of the finite element analysis step is shown in Fig. 10.

The steps for the connecting rod bearing cap bolted joint analysis are detailed below.

Discretisation of the solution domain into a finite number of elements. The bolt is discretised into 14 finite elements and is considered a bar with a variable cross section supporting a preload and axial load, as shown in Fig. 11.

Although the bolt was divided into 14 finite elements, this problem could also be solved with fewer elements. However, the fact that it is divided into more elements does not bring much calculation cost. In addition, although more stress concentrations were estimated due to the notch effect at the bolt head, the notch effect was not considered in terms of being compatible with the analytical method. These stress concentrations are taken into account in the calculation of safety stresses, not in calculating the current stress. If a finite element solution was made on the solid model, it would be appropriate to take more elements due to stress concentrations at the ends (in the notched regions).

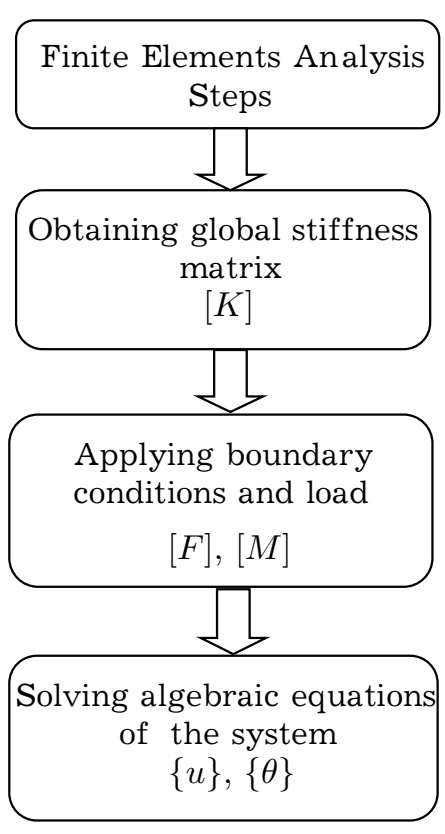

Fig. 10. Flowchart of the finite element analysis steps.

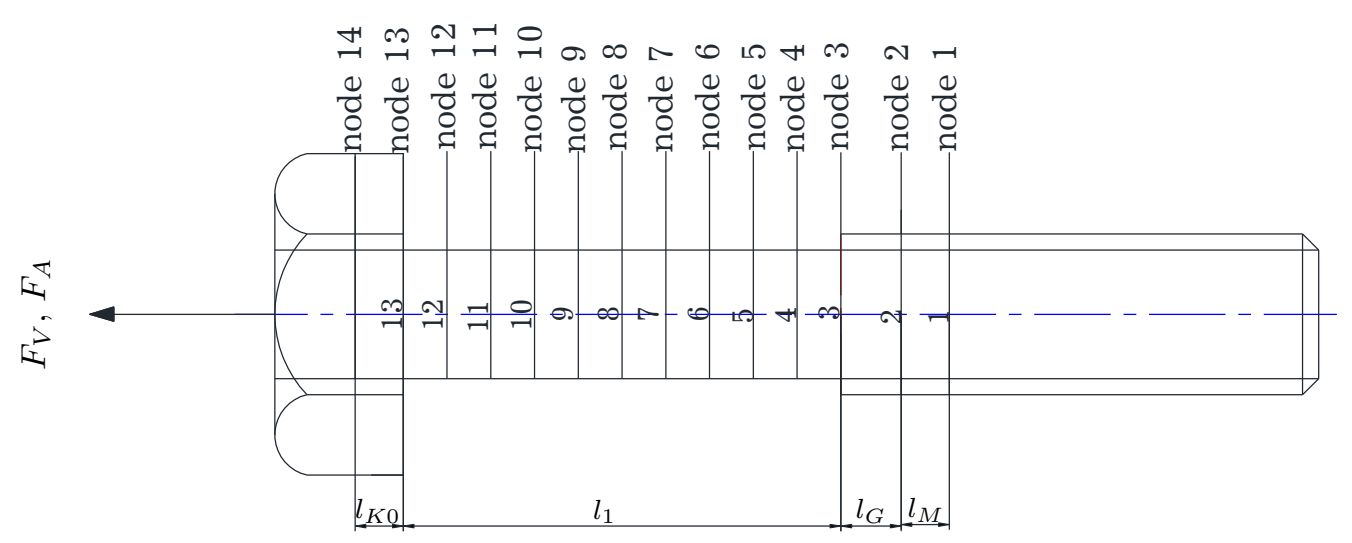

Fig. 11. Discretisation of the bolt.

The weight of the bolt is neglected. The bolt is fixed on one end and carries the loads $F_{V}$ and $F_{A}$. 
A centrally loaded element of a uniform cross section can be modelled as a spring element with an equivalent stiffness. The equivalent stiffness is written as follows $[16,17]$ :

$$
k_{e q}=\frac{A E}{l} .
$$

The equivalent stiffness for element 1 is

$$
k_{1}=\frac{E A_{N}}{l_{K 0}}
$$

The equivalent stiffness for element 2 is

$$
k_{2}=\frac{E A_{T}}{l_{k}} .
$$

The equivalent stiffness for elements $3,4,5,6,7,8,9,10$ and 11 are equal to the equivalent stiffness for element 2:

$$
k_{2}=k_{3}=k_{4}=k_{5}=k_{6}=k_{7}=k_{8}=k_{9}=k_{10}=k_{11} .
$$

The equivalent stiffness for element 12 is

$$
k_{12}=\frac{E A_{d 3}}{l_{G}}
$$

The equivalent stiffness for element 13 is

$$
k_{13}=\frac{E A_{N}}{l_{M}}
$$

Writing the static equilibrium for each node. The sum of the forces acting on each node should be zero according to static equilibrium. This requirement creates the following fourteen equations, which describe the static equilibrium for each node:

$$
\begin{aligned}
\text { Node 1: } & R_{1}-k_{1}\left(u_{2}-u_{1}\right)=0, \\
\text { Node 2: } & k_{1}\left(u_{2}-u_{1}\right)-k_{2}\left(u_{3}-u_{2}\right)=0, \\
\text { Node 3: } & k_{2}\left(u_{3}-u_{2}\right)-k_{3}\left(u_{4}-u_{3}\right)=0, \\
\text { Node } 4: & k_{3}\left(u_{4}-u_{3}\right)-k_{4}\left(u_{5}-u_{4}\right)=0, \\
\text { Node 5: } & k_{4}\left(u_{5}-u_{4}\right)-k_{5}\left(u_{6}-u_{5}\right)=0, \\
\text { Node 6: } & k_{5}\left(u_{6}-u_{5}\right)-k_{6}\left(u_{7}-u_{6}\right)=0, \\
\text { Node 7: } & k_{6}\left(u_{7}-u_{6}\right)-k_{7}\left(u_{8}-u_{7}\right)=0, \\
\text { Node 8: } & k_{7}\left(u_{8}-u_{7}\right)-k_{8}\left(u_{9}-u_{8}\right)=0, \\
\text { Node 9: } & k_{8}\left(u_{9}-u_{8}\right)-k_{9}\left(u_{10}-u_{9}\right)=0, \\
\text { Node 10: } & k_{9}\left(u_{10}-u_{9}\right)-k_{10}\left(u_{11}-u_{10}\right)=0, \\
\text { Node 11: } & k_{10}\left(u_{11}-u_{10}\right)-k_{11}\left(u_{12}-u_{11}\right)=0, \\
\text { Node 12: } & k_{11}\left(u_{12}-u_{11}\right)-k_{12}\left(u_{13}-u_{12}=0,\right. \\
\text { Node 13: } & k_{12}\left(u_{13}-u_{12}\right)-k_{13}\left(u_{14}-u_{13}\right)=0, \\
\text { Node 14: } & k_{13}\left(u_{14}-u_{13}\right)-F=0 .
\end{aligned}
$$

By rearranging the equilibrium equations by separating the reaction force $R_{1}$ and the applied external force $F$ from the internal forces and presenting the equilibrium equations in matrix form, we obtain matrix equation $[16,17]$ :

$$
\{R\}=[K]\{u\}-\{F\},
$$

where the reaction matrix, $\{R\}$, is a $14 \times 1$ column matrix, which is written as 


$$
\{R\}=\left\{\begin{array}{c}
-R_{1} \\
0 \\
\cdot \\
\cdot \\
\cdot \\
0
\end{array}\right\}_{14 \times 1} .
$$

Obtaining the global stiffness matrix. The stiffness matrix of bolt for tensile stress $[K]_{\sigma}^{G}$ is a $14 \times 14$ square matrix, which is written as

$$
[K]_{\sigma}^{G}=\left[\begin{array}{c}
\text { square } \\
\text { matrix }
\end{array}\right]_{14 \times 14} .
$$

The displacement matrix $\{u\}$ is a $14 \times 1$ column matrix, which is written as

$$
\{u\}=\left\{\begin{array}{c}
u_{1} \\
u_{2} \\
\cdot \\
\cdot \\
\cdot \\
u_{14}
\end{array}\right\}_{14 \times 1} .
$$

The load matrix $\{F\}$ is a $1 \times 14$ column matrix, which is written as

$$
\{F\}=\left\{\begin{array}{c}
0 \\
\cdot \\
\cdot \\
\cdot \\
F
\end{array}\right\}_{14 \times 1},
$$

where the stiffness matrix of the bolt for torsional stress $[K]_{\tau}^{G}$ is written as

$$
[K]_{\tau}^{G}=\left[\begin{array}{c}
\text { square } \\
\text { matrix }
\end{array}\right]_{14 \times 14}
$$

where the equivalent stiffness for element 1 is written as

$$
k_{1}=\frac{J_{1} \cdot G}{l_{K 0}} .
$$

The equivalent stiffness for element 2 is written as

$$
k_{2}=\frac{J_{2} G}{l_{k}}
$$

The equivalent stiffness for elements $3,4,5,6,7,8,9,10$ and 11 is equal to the equivalent stiffness for element 2:

$$
k_{2}=k_{3}=k_{4}=k_{5}=k_{6}=k_{7}=k_{8}=k_{9}=k_{10}=k_{11} .
$$

The equivalent stiffness for element 12 is written as

$$
k_{12}=\frac{J_{12} G}{l_{G}} .
$$

The equivalent stiffness for element 13 is written as

$$
k_{13}=\frac{J_{13} \cdot G}{l_{M}}
$$


The polar moment of inertia for element 1 is written as

$$
J_{1}=\frac{1}{2} \pi\left(\frac{d}{2}\right)^{4}
$$

The polar moment of inertia for element 2 is written as

$$
J_{2}=\frac{1}{2} \pi\left(\frac{d_{T}}{2}\right)^{4}
$$

The polar moments of inertia for elements $3,4,5,6,7,8,9,10$ and 11 are equal to the polar moment of inertia for element 2 :

$$
J_{2}=J_{3}=J_{4}=J_{5}=J_{6}=J_{7}=J_{8}=J_{9}=J_{10}=J_{11} .
$$

The polar moment of inertia for element 12 is

$$
J_{12}=\frac{1}{2} \pi\left(\frac{d_{3}}{2}\right)^{4}
$$

The polar moment of inertia for element 13 is equal to that for element 12

$$
J_{12}=J_{13} .
$$

The angle of twist matrix $\{\theta\}$ is a $14 \times 1$ column matrix:

$$
\{\theta\}=\left\{\begin{array}{c}
\theta_{1} \\
\theta_{2} \\
\cdot \\
\cdot \\
\cdot \\
\theta_{14}
\end{array}\right\}_{14 \times 1}
$$

The torque matrix $\{M\}$ is a $14 \times 1$ column matrix:

$$
\{M\}=\left\{\begin{array}{c}
0 \\
0 \\
\cdot \\
\cdot \\
\cdot
\end{array}\right\}_{14 \times 1} .
$$

Applying the boundary conditions and load. The boundary conditions and loads are applied as follows. The bar element is fixed at the top, and the displacement of node 1 is zero. Thus, there are only 13 unknown nodal displacement values, i.e., $u_{2}, u_{3}, u_{4}, \ldots, u_{14}$. The reaction force at node $1, R_{1}$, is also unknown; there are a total of 14 unknown values. Because there are 14 equilibrium equations, we should be able to solve for all of the unknown values $[16,17]$.

To eliminate the need to consider the unknown reaction force simultaneously and focus first on the unknown displacements, we employ the known boundary condition and replace the first row with a row that reads $u_{1}=0$. The application of the boundary condition $u_{1}=0$ eliminates the need to consider the unknown reaction force in our system of equations. Thus, the application of the boundary condition leads to the following matrix equation $[16,17]$ :

$$
[K]_{\sigma}^{G}\{u\}=\{F\} .
$$


Solving the algebraic equations of the system. The algebraic equations of the system are solved as follows. From Equation (1), the unknown displacements matrix $\{u\}$ can be calculated as

$$
\{u\}=[K]_{\sigma}^{G^{-1}}\{F\} .
$$

Equation (1) is re-written for the torsion of a circular shaft as

$$
[K]_{\tau}^{G}\{\theta\}=[M] .
$$

From Equation (2), the unknown angle of twist matrix $\{\theta\}$ can be calculated as

$$
\{\theta\}=[K]^{-1}\{M\} .
$$

Obtaining the stress in each element. The average stress $\sigma$ in the bar element is given by the following equation $[16,17]$ :

$$
\sigma=\frac{F}{A} \text {. }
$$

The stress and strain are related by Hooke's law over the elastic region. The tension stress is written as follows $[16,17]$ :

$$
\sigma=E \varepsilon,
$$

where $E$ is the elasticity modulus of the material, and the average normal strain $\varepsilon$ of the bar element is defined as the change in length $\Delta l$ per unit original length $l$ of the element. The average normal strain $\varepsilon$ is written as follows $[16,17]$ :

$$
\varepsilon=\frac{\Delta l}{l} .
$$

The change in length $\Delta l$ per unit can be written as

$$
\{\Delta l\}=\left\{u_{i+1}-u_{i}\right\} .
$$

Obtaining the stiffness matrix of the clamped parts. The clamped part is discretised into 12 finite elements. The clamped part is considered as a cylindrical element with a hole supporting a preload and axial load, as shown in Fig. 12. The weight of the clamped part is neglected. The clamped part is fixed at one end and carries the load $F$.

The stiffness matrix of clamped part for the tensile stress $[K]_{P}^{G}$ is a $12 \times 12$ square matrix, which is written as follows:

$$
[K]_{P}^{G}=\left[\begin{array}{c}
\text { square } \\
\text { matrix }
\end{array}\right]_{12 \times 12},
$$

where the equivalent stiffnesses for element 1 to element 11 are

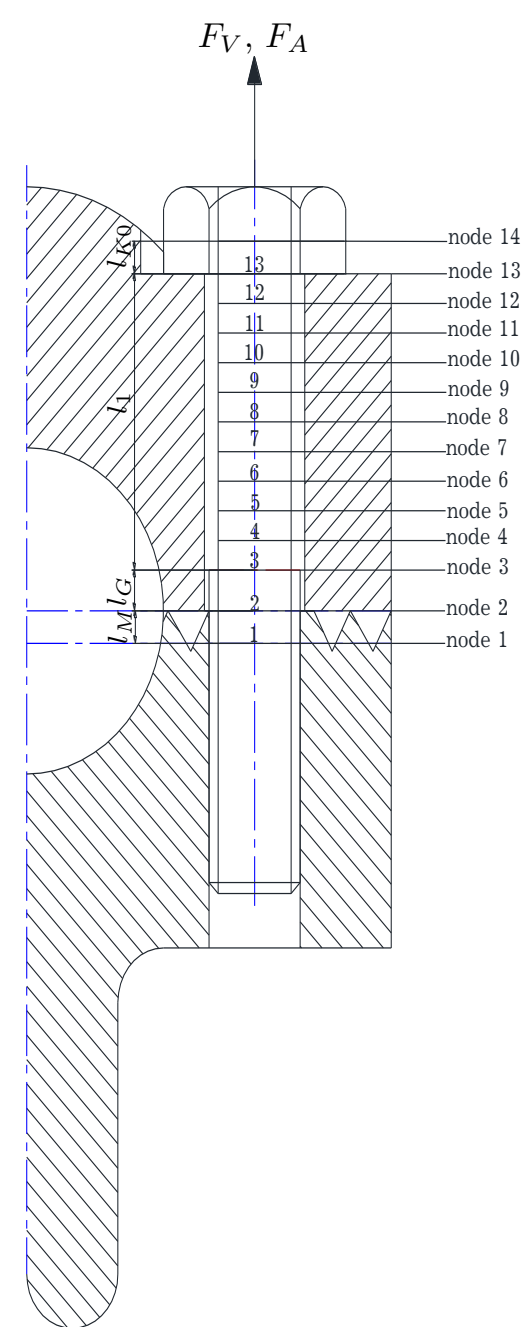

Fig. 12. Discretisation of the clamped part.

$$
k_{1}=k_{2}=k_{3}=k_{4}=k_{5}=k_{6}=k_{7}=k_{8}=k_{9}=k_{10}=k_{11}=\frac{A_{1} E}{l_{1}},
$$

where the cross sections of element 1 to element 11 are

$$
A_{1}=A_{2}=A_{3}=A_{4}=A_{5}=A_{6}=A_{7}=A_{8}=A_{9}=A_{10}=A_{11}=\frac{\pi\left(D_{A}\right)^{2}}{4}-\frac{\pi\left(d_{h}\right)^{2}}{4},
$$

where $l_{1}=l_{2}=l_{3}=l_{4}=l_{5}=l_{6}=l_{7}=l_{8}=l_{9}=l_{10}=l_{11}$ are the lengths of each element of the clamped part, $D_{A}$ is the substitutional outer diameter of the basic solid at the interface, and $d_{h}$ is the hole diameter of the clamped parts. 


\section{Numerical examples}

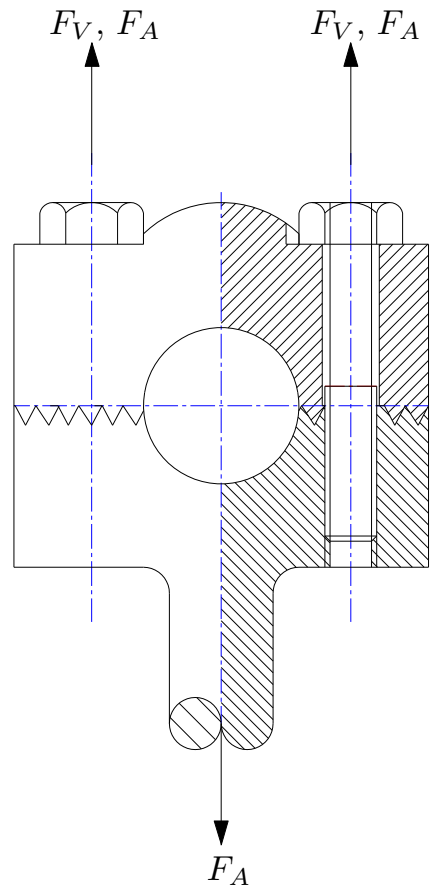

Fig. 13. Connecting the rod bearing cap bolted joint.
The rod bearing cap bolted joint is considered as an example for a simulation study. The bolt is of type M12 and is composed of 12.9 steel materials. The rod bearing cap bolted joint is shown in Fig. 13. The simulation parameters are shown in Table 1.

The assembly stress, working stress and alternating stress are calculated with both the analytical method and FE method using a MATLAB program that depends on the simulation parameters.

Table 1. Simulation parameters.

\begin{tabular}{lll}
\hline Parameters & Value & Unit \\
\hline Axial load $F_{A}$ & 6000 & {$[\mathrm{~N}]$} \\
Preload $F_{V}$ & 27000 & {$[\mathrm{~N}]$} \\
Nominal diameter $d$ for M12 & 12 & {$[\mathrm{~mm}]$} \\
Pitch diameter of the bolt thread $d_{2}$ & 10.863 & {$[\mathrm{~mm}]$} \\
Minor diameter of the bolt thread $d_{3}$ & 9.853 & {$[\mathrm{~mm}]$} \\
$\begin{array}{l}\text { Pitch of the thread } P \\
\text { Young's modulus of the nut or the }\end{array}$ & 210000 & {$\left[\mathrm{~mm} / \mathrm{mm}^{2}\right]$} \\
tapped thread region $E_{M}$ & & \\
$\begin{array}{l}\text { Young's modulus of the bolt mate- } \\
\text { rial } E_{S}\end{array}$ & 210000 & {$\left[\mathrm{~N} / \mathrm{mm}^{2}\right]$} \\
Tightening factor $\alpha_{A}$ & 1.5 & {$[-]$} \\
\hline
\end{tabular}

\subsection{Analytical calculation results}

Investigation of the bolt stiffness and plate stiffness rate. The additional axial bolt loads with respect to the bolt and plate stiffness are shown in Table 2 . The relation between the bolt stiffness rate and additional axial bolt load is shown in Fig. 14.

The analytical simulation indicated that increasing the stiffness rate of the bolt causes the axial additional bolt load $F_{S A}$ to increase. Therefore, a lower bolt stiffness rate is necessary for reducing the additional axial bolt load and alternating stresses.

The relation between the plate stiffness rate and additional axial bolt is shown in Fig. 15. The analytical simulation indicated that increasing of the stiffness rate of the clamp plate causes the axial additional bolt load $F_{S A}$ to decrease. Thus, a higher plate stiffness rate is necessary for decreasing the additional axial bolt load and alternating stresses.

Table 2. Additional axial bolt load with respect to the bolt and plate stiffness.

\begin{tabular}{llllll}
\hline Bolt stiffness & Plate stiffness & $F_{S A}$ & Bolt stiffness & Plate stiffness & $F_{S A}$ \\
$R_{S}[\mathrm{~N} / \mathrm{mm}]$ & $R_{P}[\mathrm{~N} / \mathrm{mm}]$ & {$[\mathrm{N}]$} & $R_{S}[\mathrm{~N} / \mathrm{mm}]$ & $R_{P}[\mathrm{~N} / \mathrm{mm}]$ & {$[\mathrm{N}]$} \\
\hline 50000 & 919850 & 309 & 232520 & 200000 & 3225 \\
75000 & constant & 452 & constant & 300000 & 2619 \\
100000 & constant & 588 & constant & 400000 & 2205 \\
125000 & constant & 717 & constant & 500000 & 1904 \\
150000 & constant & 841 & constant & 600000 & 1675 \\
175000 & constant & 959 & constant & 700000 & 1496 \\
200000 & constant & 1071 & constant & 800000 & 1351 \\
225000 & constant & 1179 & constant & 900000 & 1231 \\
250000 & constant & 1282 & constant & 1000000 & 1131 \\
\hline
\end{tabular}




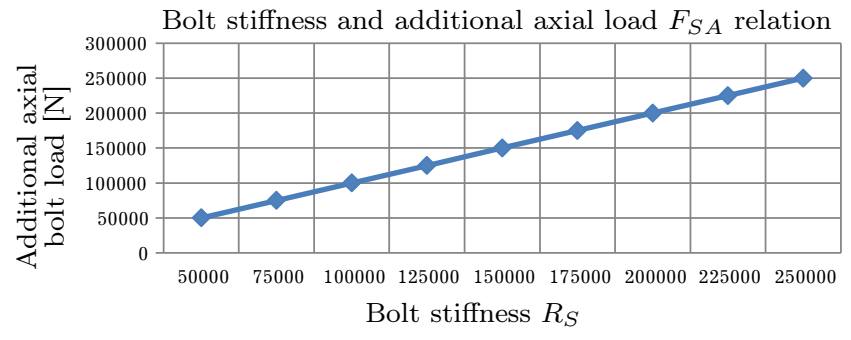

Fig. 14. Relation between the bolt stiffness rate and additional axial load.

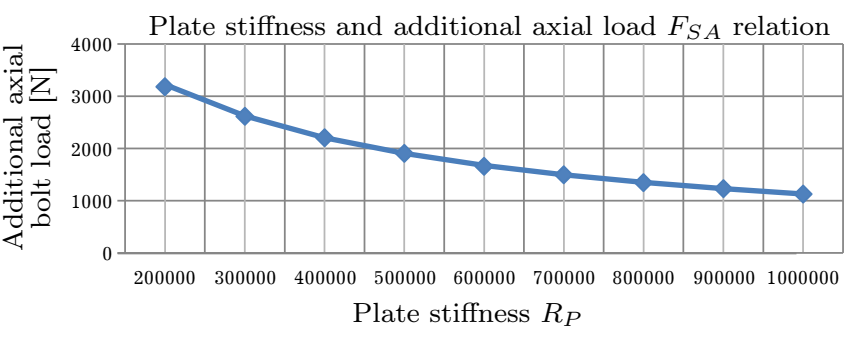

Fig. 15. Relation between the plate stiffness rate and additional axial load.
Investigation of the bolt loads using the analytical method. The analytical method calculation results of the bolt and part loads are shown in Table 3 . The analytical method calculation results indicated that increasing the load introduction factor $n$ causes the additional axial bolt load $F_{S A}$ and axial total bolt load $F_{S \max }$ to increase. The relation between the load introduction factor and additional axial load is shown in Fig 16, the relation between the load introduction factor and axial total bolt load is shown in Fig 17, and the relation between the load introduction factor and plate load is shown in Fig 18.

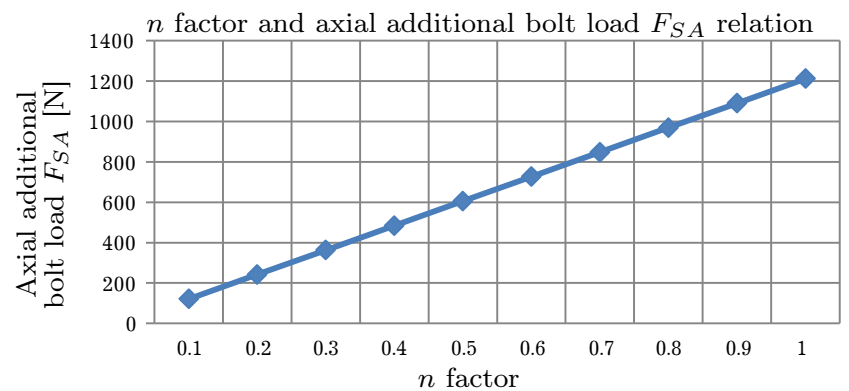

Fig. 16. Relation between the load introduction factor and additional axial bolt load.

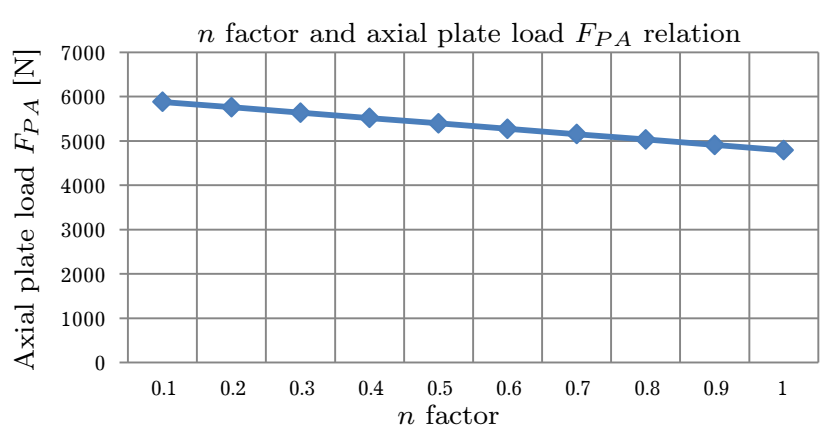

Fig. 18. Relation between the load introduction factor and axial plate load.
Table 3. Analytical method calculation results of the bolt and part loads.

\begin{tabular}{llllll}
\hline $\begin{array}{l}n \text { factor } \\
{[-]}\end{array}$ & $F_{v}$ & $F_{A}$ & $\begin{array}{l}F_{S A} \\
{[\mathrm{~N}]}\end{array}$ & $\begin{array}{l}F_{P A} \\
{[\mathrm{~N}]}\end{array}$ & $\begin{array}{l}F_{s \max } \\
{[\mathrm{N}]}\end{array}$ \\
\hline 0.1 & 27000 & 6000 & 121 & 5879 & 40621 \\
0.2 & constant & constant & 242 & 5758 & 40742 \\
0.3 & constant & constant & 363 & 5637 & 40863 \\
0.4 & constant & constant & 484 & 5516 & 40984 \\
0.5 & constant & constant & 605 & 5395 & 41105 \\
0.6 & constant & constant & 726 & 5274 & 41226 \\
0.7 & constant & constant & 847 & 5153 & 41347 \\
0.8 & constant & constant & 969 & 5031 & 41469 \\
0.9 & constant & constant & 1090 & 4910 & 41590 \\
1 & constant & constant & 1211 & 4789 & 41711 \\
\hline
\end{tabular}

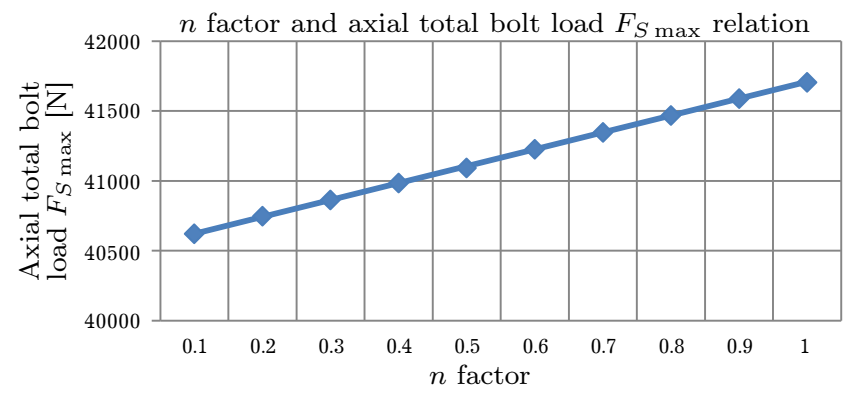

Fig. 17. Relation between the load introduction factor and total axial bolt load.

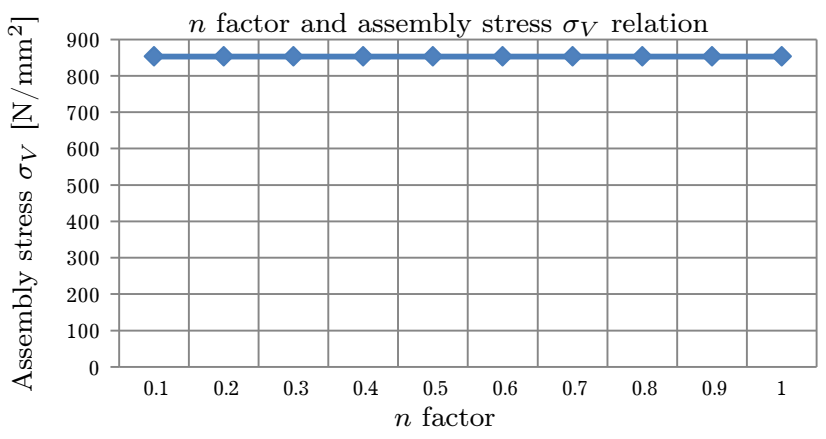

Fig. 19. Relation between the load introduction factor and assembly stress. 
Table 4. Analytical method calculation results of the bolt stresses.

\begin{tabular}{llllll}
\hline $\begin{array}{l}n \text { factor } \\
{[-]}\end{array}$ & $\begin{array}{l}\sigma_{V} \\
{\left[\mathrm{~N} / \mathrm{mm}^{2}\right]}\end{array}$ & $\begin{array}{l}\sigma_{B} \\
{\left[\mathrm{~N} / \mathrm{mm}^{2}\right]}\end{array}$ & $\begin{array}{l}\sigma_{a} \\
{\left[\mathrm{~N} / \mathrm{mm}^{2}\right]}\end{array}$ & $\begin{array}{l}S_{F} \\
{[-]}\end{array}$ & $\begin{array}{l}S_{D} \\
{[-]}\end{array}$ \\
\hline 0.1 & 853.0703 & 712.0535 & 0.9801 & 1.5448 & 34.0093 \\
0.2 & 853.0703 & 713.8646 & 1.9602 & 1.5409 & 25.5070 \\
0.3 & 853.0703 & 715.6764 & 2.9404 & 1.5370 & 17.0047 \\
0.4 & 853.0703 & 717.4890 & 3.9205 & 1.5331 & 12.7535 \\
0.5 & 853.0703 & 719.3024 & 4.9006 & 1.5293 & 10.2028 \\
0.6 & 853.0703 & 721.1166 & 5.8807 & 1.5254 & 8.5023 \\
0.7 & 853.0703 & 722.9315 & 6.8609 & 1.5216 & 7.2877 \\
0.8 & 853.0703 & 724.7472 & 7.8410 & 1.5178 & 6.3768 \\
0.9 & 853.0703 & 726.5636 & 8.8211 & 1.5140 & 5.6682 \\
1 & 853.0703 & 728.3808 & 9.8012 & 1.5102 & 5.1014 \\
\hline
\end{tabular}

Investigation of the bolt stresses using the analytical method. The analytical method calculation results of the bolt stresses are shown in Table 4 . The analytical method calculation results satisfy the safety factors $S_{F}$ and $S_{D}$. The assembly stress, working stress and alternating stresses are shown in Fig. 19, Fig. 20 and Fig. 21, respectively.

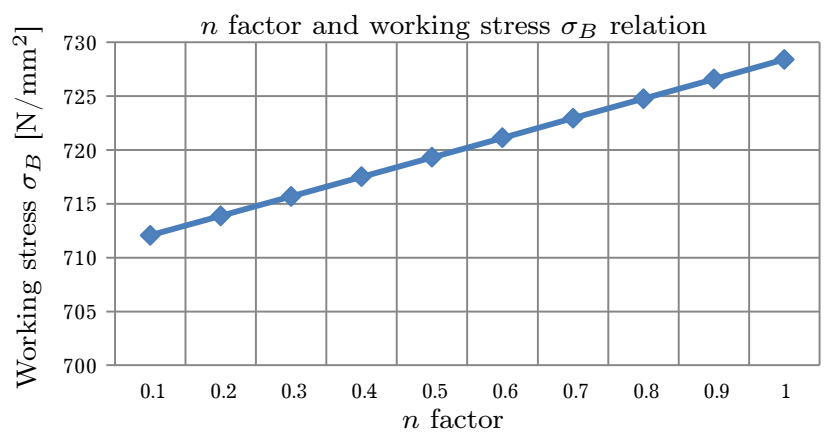

Fig. 20. Relation between the load introduction factor and working stress.

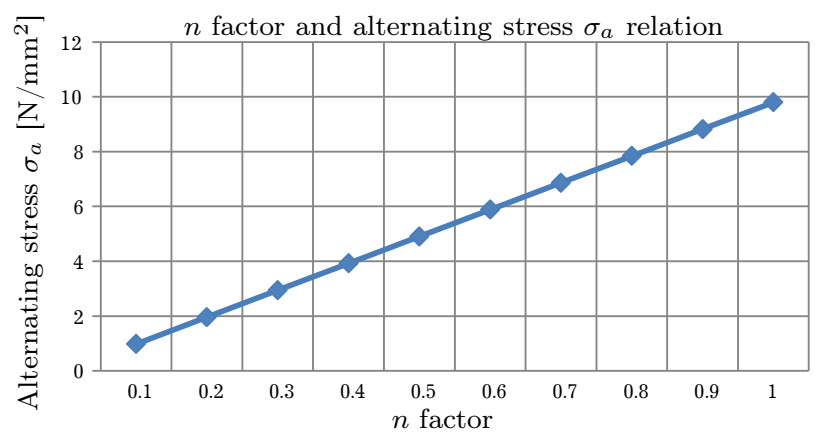

Fig. 21. Relation between the load introduction factor and alternating stress.

\subsection{Finite elements calculation results}

Investigation of the bolt loads using the finite element method. The results of the FE method calculation of the bolt loads are shown in Table 5. The finite element method calculation results indicated that increasing the load introduction factor $n$ causes the additional axial bolt load $F_{S A}$ and axial total bolt load $F_{S \max }$ to increase. The obtained results are similar to the analytical method calculation results.

Table 5. Finite element method calculation results of the bolt loads.

\begin{tabular}{llllll}
\hline $\begin{array}{l}n \text { factor } \\
{[-]}\end{array}$ & $F_{v}$ & $F_{A}$ & $\begin{array}{l}F_{S A} \\
{[\mathrm{~N}]}\end{array}$ & $\begin{array}{l}F_{P A} \\
{[\mathrm{~N}]}\end{array}$ & $\begin{array}{l}F_{s \max } \\
{[\mathrm{N}]}\end{array}$ \\
\hline 0.1 & 27000 & 6000 & 122 & 5878 & 40622 \\
0.2 & constant & constant & 245 & 5755 & 40745 \\
0.3 & constant & constant & 368 & 5632 & 40868 \\
0.4 & constant & constant & 491 & 5509 & 40991 \\
0.5 & constant & constant & 613 & 5387 & 41113 \\
0.6 & constant & constant & 736 & 5264 & 41236 \\
0.7 & constant & constant & 859 & 5141 & 41359 \\
0.8 & constant & constant & 982 & 5018 & 41482 \\
0.9 & constant & constant & 1105 & 4895 & 41605 \\
1 & constant & constant & 1228 & 4772 & 41728 \\
\hline
\end{tabular}


Investigation of the bolt stresses using the finite element method. The stresses are shown in Table6. The local stress for each element is shown in Table 7. Thus, the finite element calculations indicate suitable values for $S_{F}$ and $S_{D}$. The assembly stress, working stress and alternating stresses are shown in Fig. 22, Fig. 23 and Fig. 24, respectively.

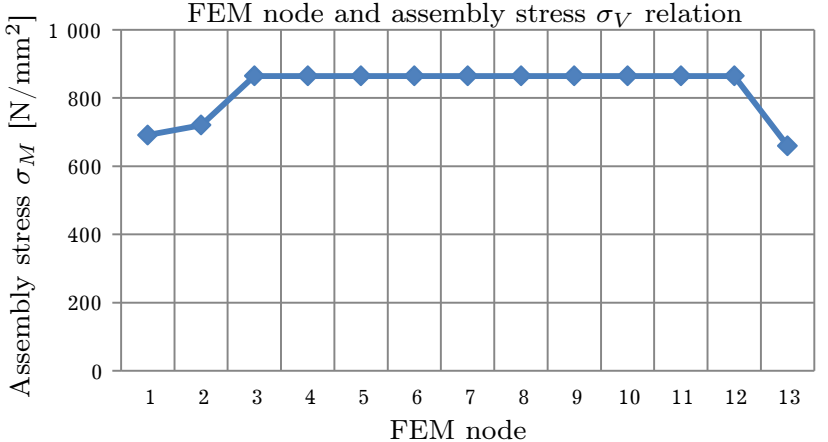

Fig. 22. Relation between the FEM node and assembly stress.

Table 6. Finite element method calculation results of the bolt stresses.

\begin{tabular}{llllll}
\hline $\begin{array}{l}n \text { factor } \\
{[-]}\end{array}$ & $\begin{array}{l}\sigma_{V} \\
{\left[\mathrm{~N} / \mathrm{mm}^{2}\right]}\end{array}$ & $\begin{array}{l}\sigma_{B} \\
{\left[\mathrm{~N} / \mathrm{mm}^{2}\right]}\end{array}$ & $\begin{array}{l}\sigma_{a} \\
{\left[\mathrm{~N} / \mathrm{mm}^{2}\right]}\end{array}$ & $\begin{array}{l}S_{F} \\
{[-]}\end{array}$ & $\begin{array}{l}S_{D} \\
{[-]}\end{array}$ \\
\hline 0.1 & 864.5631 & 721.2018 & 1.0068 & 1.5252 & 31.0410 \\
0.2 & 864.5631 & 723.0653 & 2.0135 & 1.5213 & 24.8328 \\
0.3 & 864.5631 & 724.9288 & 3.0202 & 1.5174 & 18.6246 \\
0.4 & 864.5631 & 726.7923 & 4.0269 & 1.5135 & 12.4164 \\
0.5 & 864.5631 & 728.6498 & 5.0336 & 1.5096 & 10.3470 \\
0.6 & 864.5631 & 730.5074 & 6.0404 & 1.5058 & 8.2776 \\
0.7 & 864.5631 & 732.3741 & 7.0471 & 1.5019 & 7.2429 \\
0.8 & 864.5631 & 734.2409 & 8.0539 & 1.4981 & 6.2082 \\
0.9 & 864.5631 & 736.1092 & 9.0606 & 1.4943 & 5.5874 \\
1 & 864.5631 & 737.9775 & 10.0673 & 1.4906 & 4.9666 \\
\hline
\end{tabular}

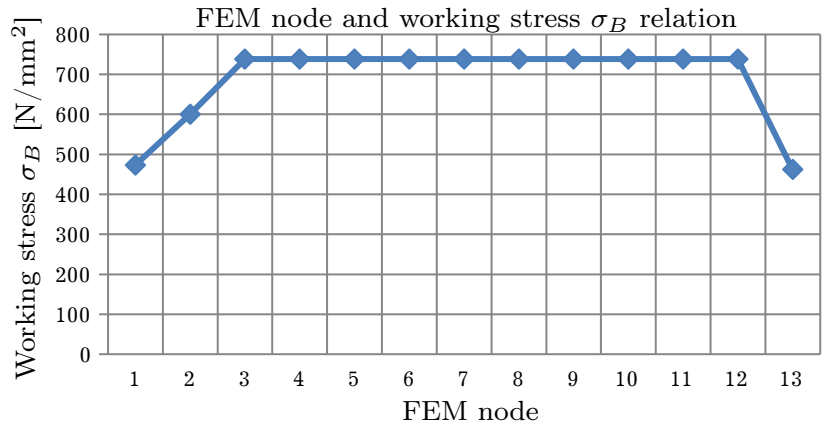

Fig. 23. Relation between the FEM node and working stress.

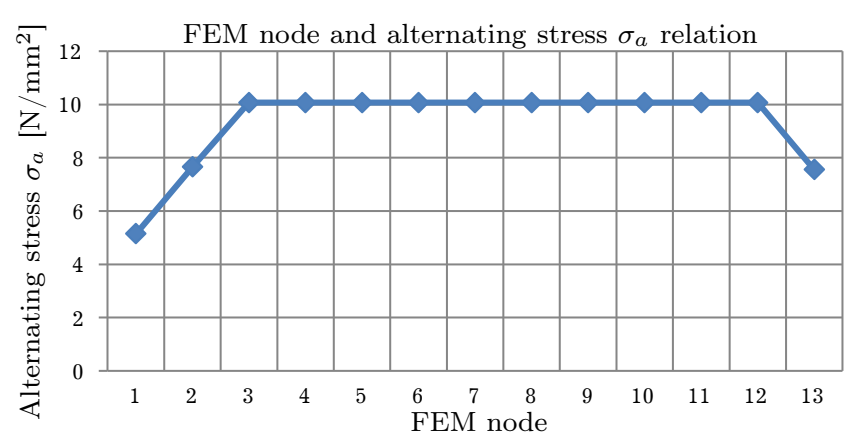

Fig. 24. Relation between the FEM node and alternating stress.

Table 7. Finite element method calculation results for each element.

\begin{tabular}{llllll}
\hline$n=1$ & $\sigma_{V}$ & $\sigma_{B}$ & $\sigma_{a}$ & $S_{F}$ & $S_{D}$ \\
Element number & {$\left[\mathrm{N} / \mathrm{mm}^{2}\right]$} & {$\left[\mathrm{N} / \mathrm{mm}^{2}\right]$} & {$\left[\mathrm{N} / \mathrm{mm}^{2}\right]$} & {$[-]$} & {$[-]$} \\
\hline 1 & 690.9176 & 472.8545 & 5.1473 & 2.3263 & 9.7138 \\
2 & 720.1780 & 600.1072 & 7.6532 & 1.8330 & 6.5332 \\
$\mathbf{3}$ & $\mathbf{8 6 4 . 5 6 3 1}$ & $\mathbf{7 3 7 . 9 7 7 5}$ & $\mathbf{1 0 . 0 6 7 3}$ & $\mathbf{1 . 4 9 0 6}$ & $\mathbf{4 . 9 6 6 6}$ \\
$\mathbf{4}$ & $\mathbf{8 6 4 . 5 6 3 1}$ & $\mathbf{7 3 7 . 9 7 7 5}$ & $\mathbf{1 0 . 0 6 7 3}$ & $\mathbf{1 . 4 9 0 6}$ & $\mathbf{4 . 9 6 6 6}$ \\
$\mathbf{5}$ & $\mathbf{8 6 4 . 5 6 3 1}$ & $\mathbf{7 3 7 . 9 7 7 5}$ & $\mathbf{1 0 . 0 6 7 3}$ & $\mathbf{1 . 4 9 0 6}$ & $\mathbf{4 . 9 6 6 6}$ \\
$\mathbf{6}$ & $\mathbf{8 6 4 . 5 6 3 1}$ & $\mathbf{7 3 7 . 9 7 7 5}$ & $\mathbf{1 0 . 0 6 7 3}$ & $\mathbf{1 . 4 9 0 6}$ & $\mathbf{4 . 9 6 6 6}$ \\
$\mathbf{7}$ & $\mathbf{8 6 4 . 5 6 3 1}$ & $\mathbf{7 3 7 . 9 7 7 5}$ & $\mathbf{1 0 . 0 6 7 3}$ & $\mathbf{1 . 4 9 0 6}$ & $\mathbf{4 . 9 6 6 6}$ \\
$\mathbf{8}$ & $\mathbf{8 6 4 . 5 6 3 1}$ & $\mathbf{7 3 7 . 9 7 7 5}$ & $\mathbf{1 0 . 0 6 7 3}$ & $\mathbf{1 . 4 9 0 6}$ & $\mathbf{4 . 9 6 6 6}$ \\
$\mathbf{9}$ & $\mathbf{8 6 4 . 5 6 3 1}$ & $\mathbf{7 3 7 . 9 7 7 5}$ & $\mathbf{1 0 . 0 6 7 3}$ & $\mathbf{1 . 4 9 0 6}$ & $\mathbf{4 . 9 6 6 6}$ \\
$\mathbf{1 0}$ & $\mathbf{8 6 4 . 5 6 3 1}$ & $\mathbf{7 3 7 . 9 7 7 5}$ & $\mathbf{1 0 . 0 6 7 3}$ & $\mathbf{1 . 4 9 0 6}$ & $\mathbf{4 . 9 6 6 6}$ \\
$\mathbf{1 1}$ & $\mathbf{8 6 4 . 5 6 3 1}$ & $\mathbf{7 3 7 . 9 7 7 5}$ & $\mathbf{1 0 . 0 6 7 3}$ & $\mathbf{1 . 4 9 0 6}$ & $\mathbf{4 . 9 6 6 6}$ \\
$\mathbf{1 2}$ & $\mathbf{8 6 4 . 5 6 3 1}$ & $\mathbf{7 3 7 . 9 7 7 5}$ & $\mathbf{1 0 . 0 6 7 3}$ & $\mathbf{1 . 4 9 0 6}$ & $\mathbf{4 . 9 6 6 6}$ \\
13 & 659.6333 & 461.5503 & 7.5505 & 2.3833 & 6.6221 \\
\hline
\end{tabular}




\section{Results and discussion}

The analytical method calculation results and finite element method calculation results are compared below:

- The assembly stress $\sigma_{v}$ obtained with the finite element method is $1.32 \%$ higher than that obtained in the analytical calculations.

- The working stress $\sigma_{B}$ obtained with the finite element method is $1.30 \%$ higher than that obtained in the analytical calculations.

- The alternating stress $\sigma_{a}$ obtained with the finite element method is $2.65 \%$ higher than that obtained in the analytical calculations.

- Both the analytical method calculation results and finite element method calculation results have suitable safety factors $S_{F}$ and $S_{D}$.

\section{Conclusions}

This study systematically investigated concentrically clamped bolted joints. The bolt and part loads were analytically calculated based on the axial load. The assembly stress, working stress and alternating stress were calculated and simulated based on the load introduction factor $n$.

The finite element equations were obtained for the rod bearing cap bolted joints. The assembly stress, working stress and alternating stress were calculated using a finite element model. The results obtained from the analytical calculations and finite element calculations were compared and were found to be highly similar in terms of the assembly stress, working stress and alternating stress.

In this study, both the analytical calculations and finite element calculations were based on the VDI 2230 directive. All obtained equations used in the finite element calculations were written in matrix form, and the results were obtained through matrix operations.

The obtained analytical and finite element results were highly similar, demonstrating that the proposed method is reliable. An experimental study was not considered and performed. During the modelling of the clamped parts, the sealing element and nut type were ignored. The following conclusions are drawn:

1. The increase of the stiffness rate of the bolt causes the bolt load to increase. Thus, a lower bolt stiffness rate is necessary for reducing the additional axial bolt load and alternating stresses.

2. In contrast, the increase of the stiffness rate of the clamp part causes the bolt load to decrease. Thus, a higher plate stiffness rate is necessary for decreasing the additional axial bolt load and alternating stresses.

3. The stiffness of the bolt should be as low as possible to reduce the maximum bolt load and stress of the bolt cross-sections. However, the stiffness of the clamped part should be as high as possible.

4. Increasing load introduction factor causes the bolt load to increase. Thus, increasing the load introduction factors causes the assembly stress and alternating stress to increase in concentrically bolted joints.

5. The finite element method enables the stress of each individual element and the critical cross section under the maximum stress to be determined. Thus, the failure point of the bolt under an axial load is estimated more precisely.

6. The results obtained by means of the analytical method and the finite element method have suitable values for the safety factors $S_{F}$ and $S_{D}$.

The above conclusions demonstrate that the obtained finite element model is valid for calculating all of the stresses on the concentrically clamped rod bearing cap bolted joints, including the assembly stress, working stress, and alternating stress. However, the conventional analytical method is a simple and reliable method for the bolt connection calculation. Therefore, there is no need to use such complex mathematical models for the considered type of bolted joints during engineering applications. 
In future works, the author plans to carry out a study that includes both the contact problem and the eccentrically mounted bolt problem.

A reliability-based study is necessary for probabilistic results for new bolt products to guarantee the bolt service life. Thus, manufacturer prestige is of high importance in the market depending on the reliability level of their products. Therefore, the bolt static and dynamic load-carrying capacities and bolt fatigue life will the objects of the experimental investigation of the author in a future study.

\section{Acknowledgements}

The author thanks Prof. Dr.-Ing. H. Haberhauer, Prof. Dr.-Ing. W. Czarnetzki, Dr.-Ing. N. Babel, and Dr.-Ing. U. Schwanke, for their helpful co-operation of Faculty of Mechanical Engineering, Hochschule Esslingen-University of Applied Science.

[1] Pedersen N.L., Pedersen P. Bolt-plate contact assemblies with prestress and external loads: Solved with super element technique. Computers \& Structures. 87 (21-22), 1374-1383 (2009).

[2] Chakhari J., Daidié A., Chaib Z., Guillot J. Numerical model for two-bolted joints subjected to compressive loading. Finite Elements in Analysis and Design. 44 (4), 162-173 (2008).

[3] Fares Y., Chaussumier M., Daidie A., Guillot J. Determining the life cycle of bolts using a local approach and the Dang Van criterion. Fatigue and Fracture of Engineering Materials and Structures. 29 (8), 588-596 (2006).

[4] Venkatesan S., Kinzel G. L. Reduction of Stress Concentration in Bolt-Nut Connectors. Journal of Mechanical Design. 128 (6), 1337-1342 (2005).

[5] Bhonge P.S., Foster B. D., Lankarani H. M. Finite Element Modeling and Analysis of Structural Joints Using Nuts and Bolts. Proceedings of the ASME 2011 International Mechanical Engineering Congress and Exposition. Vol. 3: Design and Manufacturing. Denver, Colorado, USA. November 11-17, 2011. pp. 73-83.

[6] Kim J., Yoon J.-C., Kang B.-S. Finite element analysis and modeling of structure with bolted joints. Applied Mathematical Modelling. 31 (5), 895-911 (2007).

[7] Piraprez E. The effect of prying stress ranges on fatigue behaviour of bolted connections: The state-of-theart. Journal of Constructional Steel Research. 27 (1-3), 55-68 (1993).

[8] Friede R., Lange J. Loss of Preload in Bolted Connections Due to Embedding and Self Loosening. In SDSS' Rio 2010 Stability and Ductility of Steel Structures, edited by E. Batista, P. Vellasco, and L de Lima, 287294 (2010). Rio de Janeiro, Brazil.

[9] Stephen J. T, Marshall M. B., Lewis R. Relaxation of contact pressure and self-loosening in dynamic bolted joints. Proceedings of the Institution of Mechanical Engineers, Part C: Journal of Mechanical Engineering Science. 231 (18), 3462-3475 (2016).

[10] Gong Hao, Liu Jianhua. Some factors affecting the loosening failure of bolted joints under vibration using finite element analysis. Proceedings of the Institution of Mechanical Engineers, Part C: Journal of Mechanical Engineering Science. 232 (21), 3942-3953 (2017).

[11] PoljakS., Bašt'ovanský R. Vibration Resistance of High Speed Assembly Secured Bolted Joint with Nut DIN 985. Modern Methods of Construction Design. 299-305 (2014).

[12] VDI-Richtlinien 2230: Systematische Berechnung Hochbeanspruchter Schraubenverbindungen Zylindrische Einschraubenverbindungen.

[13] Haberhauer H., Bodenstein F. Maschinenelemente. Springer (2009).

[14] Wittel H., Becker M. Roloff/Matek Maschinenelemente Aufgabensammlung. Wiesbaden, Vieweg\&Sohn Verlag/Fachverlage GmbH (2005).

[15] Kabus K., Decker K. Maschinenelemente Formeln. Carl Hanser Verlag (2009).

[16] Moaveni S. Finite Element Analysis Theory and Application with ANSYS. New Jersey, Prentice Hall (2003).

[17] Chandrupatla T. R., Belegundu A. D. Introduction to Finite Elements in Engineering. New Jersey, Prentice Hall (2002). 


\section{Appendix}

The stiffness matrix of bolt for tensile stress $[K]_{\sigma}^{G}$ is a $14 \times 14$ square matrix:

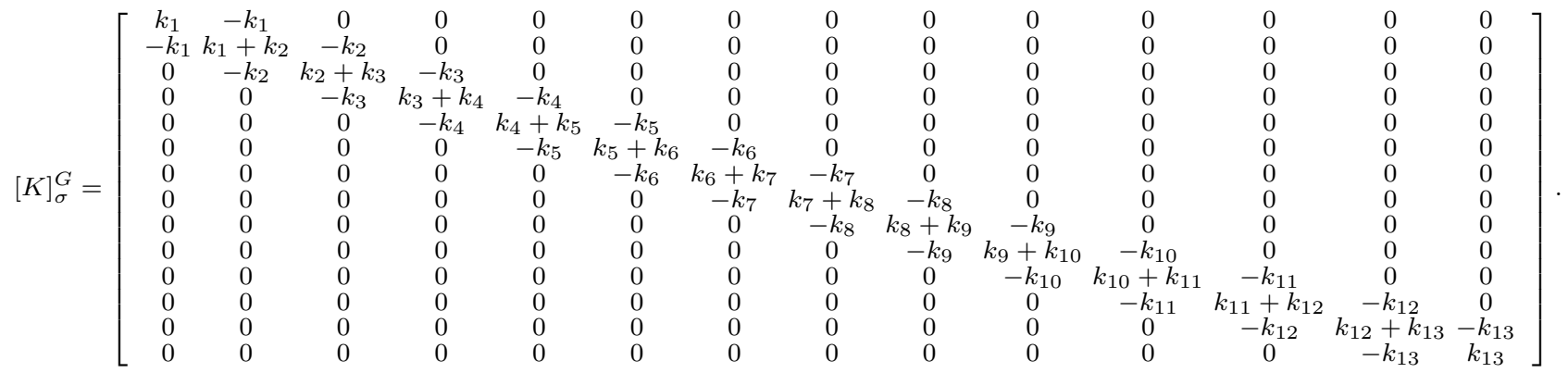

The stiffness matrix of the bolt for torsional stress $[K]_{\tau}^{G}$ is $14 \times 14$ square matrix:

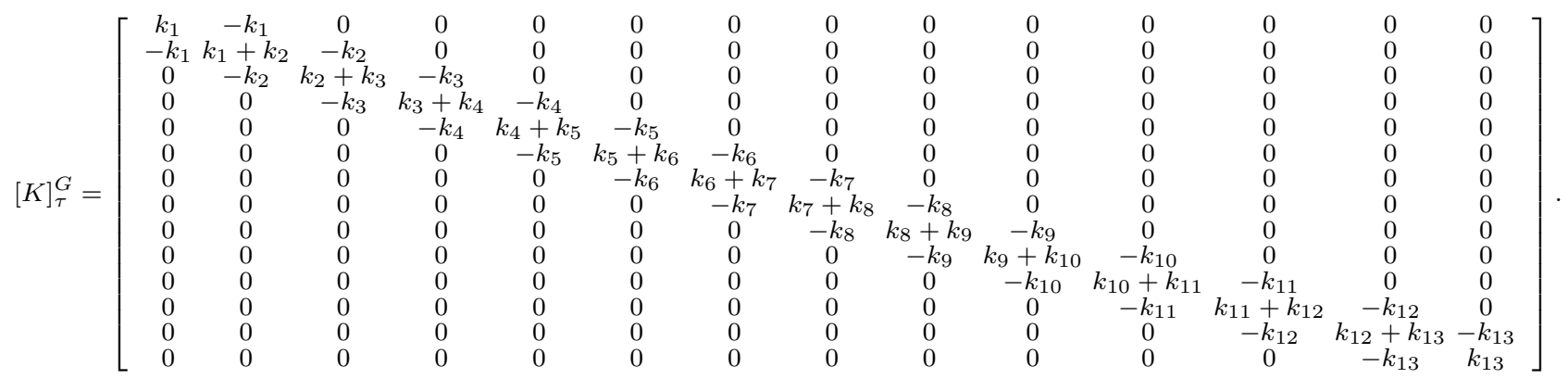

The stiffness matrix of clamped part for the tensile stress $[K]_{P}^{G}$ is a $12 \times 12$ square matrix:

$$
[K]_{P}^{G}=\left[\begin{array}{cccccccccccc}
k_{1} & -k_{1} & 0 & 0 & 0 & 0 & 0 & 0 & 0 & 0 & 0 & 0 \\
-k_{1} & k_{1}+k_{2} & -k_{2} & 0 & 0 & 0 & 0 & 0 & 0 & 0 & 0 & 0 \\
0 & -k_{2} & k_{2}+k_{3} & -k_{3} & 0 & 0 & 0 & 0 & 0 & 0 & 0 & 0 \\
0 & 0 & -k_{3} & k_{3}+k_{4} & -k_{4} & 0 & 0 & 0 & 0 & 0 & 0 & 0 \\
0 & 0 & 0 & -k_{4} & k_{4}+k_{5} & -k_{5} & 0 & 0 & 0 & 0 & 0 & 0 \\
0 & 0 & 0 & 0 & -k_{5} & k_{5}+k_{6} & -k_{6} & 0 & 0 & 0 & 0 & 0 \\
0 & 0 & 0 & 0 & 0 & -k_{6} & k_{6}+k_{7} & -k_{7} & 0 & 0 & 0 & 0 \\
0 & 0 & 0 & 0 & 0 & 0 & -k_{7} & k_{7}+k_{8} & -k_{8} & 0 & 0 & 0 \\
0 & 0 & 0 & 0 & 0 & 0 & 0 & -k_{8} & k_{8}+k_{9} & -k_{9} & 0 & 0 \\
0 & 0 & 0 & 0 & 0 & 0 & 0 & 0 & -k_{9} & k_{9}+k_{10} & -k_{10} & 0 \\
0 & 0 & 0 & 0 & 0 & 0 & 0 & 0 & 0 & -k_{10} & k_{10}+k_{11} & -k_{11} \\
0 & 0 & 0 & 0 & 0 & 0 & 0 & 0 & 0 & 0 & -k_{11} & k_{11}
\end{array}\right] .
$$




\title{
Систематичне дослідження напружень у концентрично затиснутих болтових з'єднаннях методом скінченних елементів
}

\author{
Бозча М. \\ Технічний університет Йилдиз, факультет машинобудування, \\ 34349 Йилдиз, Стамбул, Туреччина
}

У цій статті систематично досліджувалися напруження, які виникають в болтовому з'єднанні кришки стрижневого підшипника з урахуванням специфіки концентрично затисненого болтового з'єднання. Метою даного дослідження є розроблення двовимірної моделі скінченних елементів для визначення виникаючих напружень у болтових з'єднаннях у всіх випадках болтових з'єднань і порівняння директиви VDI. Для цієї мети навантаження на болт і часткове навантаження розраховуються аналітично на основі осьового навантаження. Робоче напруження, збірне напруження і змінне напруження розраховуються і моделюються на основі коефіцієнта введеного навантаження $n$. Розроблено двовимірну скінченно-елементну модель. Для цього отримано глобальну матрицю жорсткості $[K]$, застосовуються граничні умови і навантаження, такі як сила $[F]$ і момент $[M]$. Розв'язуючи алгебраїчні рівняння системи, ми отримуємо вузлове зміщення $\{u\}$ i $\{\theta\}$, збірне напруження $\sigma_{v}$, робоче напруження $\sigma_{B} \mathrm{i}$ змінне напруження $\sigma_{a}$ в кожному елементі системи. Встановлено рівняння скінченних елементів для болта. Збірне напруження, робоче напруження і змінне напруження розраховуються з використанням розробленої скінченно-елементної моделі. Результати аналітичних розрахунків і результати розрахунків методом скінченних елементів порівнюються і виявляються дуже схожими з точки зору збірного робочого напруження і змінного напруження. Збільшення коефіцієнта жорсткості болта викликає збільшення навантаження на болт і змінних напружень; навпаки, збільшення коефіцієнта жорсткості затисненої частини болта призводить до зменшення навантаження на болт і змінних напружень. Жорсткість болта повинна бути якомога нижчою, щоб знизити максимальне навантаження на болт і напруження поперечних перерізів болта. Однак жорсткість затиснутої частини повинна бути якомога більшою. Крім того, збільшення коефіцієнта введення навантаження призводить до збільшення навантаження на болт. Отже, для концентричних болтових з'єднань збільшення коефіцієнта введення навантаження призводить до збільшення збірного напруження і змінного напруження.

Ключові слова: болтові з'єднання, монтажне напруження, робоче напруження, змінне напруження, скінченний елемент. 